\title{
Contents of Classroom Management: What Is Necessary, What Is Possible, How Is It Done at School?
}

\author{
Gisela Steins*, Katharina Wittrock, Anna Haep \\ University of Duisburg-Essen, Duisburg and Essen, Germany \\ Email: "gisela.steins@uni-due.de
}

Received 24 September 2015; accepted 16 November 2015; published 19 November 2015

Copyright @ 2015 by authors and Scientific Research Publishing Inc.

This work is licensed under the Creative Commons Attribution International License (CC BY). http://creativecommons.org/licenses/by/4.0/

(c) (i) Open Access

\begin{abstract}
Classroom Management (CM) comprises broad knowledge and skills of teachers. Since CM has been only given little proportion in teacher education, knowledge about the relevance and usefulness of CM contents (CMC) is important. We want to contribute to the knowledge about relevant CMC with four studies. These studies explore the following research questions: Which CMC are needed? What is possible? Are CMC useful for teaching at school? All studies are carried out with the participation of teacher students. In Study 1, we explore the baseline of Classroom Management Knowledge (CMK) of teacher students to deal with challenging situations $(N=158)$. Study 2 , we explore the CMK baseline of teacher students and examines whether CMK which is acquired in a classical seminar can lead to an increase in CMK $(N=17$; T1, T2). In Study 3, CMK is validated: How does it affect the practical knowledge of teacher students $(N=58$; T1, T2) when facing challenging situations? Finally, we examine the question of Study 4 that asks whether CMK in the classroom can be converted into skills at school $(N=13)$. The results show that a significant increase in CMK is acquired through a seminar; but the acquired knowledge is very unlikely to be transferred without an intense, long lasting and supportive training of skills. The relevance of these findings is critically related to teacher education.
\end{abstract}

\section{Keywords}

Classroom Management, Transfer of Knowledge, Teacher-Student Interaction

\section{Introduction}

The German teacher education consists of two phases. The first phase takes place at the university and is about "Corresponding author. 
four to five years, during which, teacher students study two teaching subjects and general courses in educational topics. Classroom management (CM) is usually a voluntary topic of educational courses. Then, the "Referendariat" starts, a teacher training of 18 months at school. The Referendariat is a kind of apprenticeship and several teacher educators are involved (for more detail about Teacher Education in Germany see Dicke, Elling, Schmeck, \& Leutner, 2015, p: 2; Howe, 2006). In both phases, Classroom Management Knowledge (CMK) is underrepresented. The systematic teaching of CM is not assured; CMK is rarely obligatory and usually only a topic of a single-standing lecture.

Our research deals with the question of how a substantive arrangement of CMK can be effective in the first phase of teacher training. In our research, we want to examine whether and how CMK can be a systematic component, at least in the initial training phase. The following theoretical reflections aim to approach the research questions, which CMCs are essential and then will move further into four studies on these issues.

\section{What Is Classroom Management?}

When it comes to skills for dealing with students and managing complexity, reference is often made to CM research. CM is a term that has been defined in many different ways (Reupert \& Woodcock, 2010). CM includes at least “... teacher strategies that oversee students' behavior, students' interactions and learning” (Reupert et al., p. 1261). However, Reupert et al. (2010) pointed out that CM is an umbrella term and is not defined consistently.

CM is very often equated with order and discipline, especially by students of Teacher Education (Stoughton, 2007; Wolff, van den Bogert, Jarodzka, \& Boshuizen, 2015). In fact, the field of CM is a lot wider. Many researchers emphasize the importance of effective behavior management (Stoughton, 2007) and define CM as an important sub domain of teaching (Weiner \& Lingelbach, 1995). Also CM is necessary within general pedagogical/psychological knowledge called procedural knowledge (Voss, Kunter, \& Baumert, 2011).

Definitions of CM include a wide range of perspectives, on one hand taking care of students as individuals and on the other hand taking care of the class as a whole. Thus, CM includes individual support, which is specifically addressed in Evertson and Weinstein's (2006) definition with respect to the cognitive, emotional, and moral development of students. CM also includes skills for dealing with a large study group and the potential problems related to such a situation (Dollase, 2012). Kounin (1970) has earlier introduced this group-oriented view in CM research and demonstrated very clearly that special teachers' behaviors increase the probability of students' participation and decrease disruptions. Kounins' research results yielded helpful insights into dimensions of teachers' behavior that can reduce complexity. Dollase (2012) pointed out that complexity in the classroom, increased by variables such as the heterogeneity of the students, their fluctuating self-control, viscosity, coordination, synchronization problems, and loss of motivation can become even more complicated because of two more dimensions. One of these dimensions concerns the public nature of teaching that leads to problems such as the audience effect, intrapersonal processes of social comparisons, the collective validity of information, and the risk of discrimination. In order to deal with the effect of the public nature of teaching in an appropriate manner, a teacher can try to avoid discussing students' failures in public. A teacher may have available acceptance, empathy, praise, humor, and justice and be able to establish friendly interactions and provide support for the self-regulation of individual students (Dollase, 2012). The other dimension concerns the relationship structure that is inevitably formed among students and can lead to the emergence of majority/minority conflicts between subgroups and undesired composition effects (Dollase, 2012). Complexity, the public and relationship structure result from the fact that teaching takes place in a group and not in a 1:1 interaction.

CM competencies are not only important for teachers to enable them to cope with the tension of individual support and group management but also are as important for the students. CM has certainly a powerful influence on students' achievements. The effects of CM are greater than students' general intelligence, home environment, motivation, and socio-economic status (Weinstein, Tomlinson-Clarke, \& Curran, 2004). In spite of this knowledge about the relevance of CMK and CM skills for teachers, teacher students and students, CM research has still not been systematically integrated with Teacher Education (Evertson \& Weinstein, 2006; Jones, 2006; O’Neill \& Stephenson, 2012; Piwowar, Thiel, \& Ophardt, 2013; Stough, 2006). Analyses show that courses devoted exclusively to CM are underrepresented in the US, but it is strongly applied in special education or for exceptional children. CMK is neither a binding content nor belongs to competency standards in teacher training (Stough, 2006). 


\section{What Do Teacher Students Know about CM?}

One of the key findings of various studies on the knowledge of student teachers is known by the keyword "apprenticeship of observation” (Lortie, 1975). Many researchers in the field of CM and related topics refer repeatedly to the fact that many teacher students have formed their basic beliefs about the way to teach and how to deal with people within the school context by observing their own teachers (Balli, 2011; Blömeke, Buchholtz, Suhl, \& Kaiser, 2014; Brouwer \& Korthagen, 2005; Hattie, 2009; Jones, 2006; Löfström \& Poom Valickis, 2013; Stoughton, 2007).

Jones concludes that:

Teacher educators must attend to the fact that the experiences and associated preexisting beliefs prospective teachers bring with them will serve as a filter for their interpretation and response to the CM content presented in their university courses. These beliefs and experiences influence the manner in which novice teachers develop their image of themselves as teachers. It is therefore important that educators understand these beliefs and incorporate methods that help preservice students examine their beliefs and consider alternative ways of viewing themselves and their interactions with students (Jones, 2006: p. 895).

These preexisting beliefs of prospective teachers also relate to the handling of ethnic diversity (Den Brok \& Levy, 2005).

Stoughton (2007) noted that there are many disconnections between what pre-service teachers believe about teaching, what they learn in their university coursework, and what they observe in behavior management practices in public school classrooms. This situation raises the question that if it is not the lack of having insight in these preexisting beliefs during teacher education along with the lack of problem solving methods in education, then, what makes teacher students stick to their early observations as students?

In summary, there is only an unsystematic CMK available in Germany and many other countries even after graduation and the Referendariat (Dicke et al., 2015).

\section{What Should Teacher Students Know about CM?}

CM research, like any other complex domain, offers a variety of models allowing a systematic view. O’Neill and Stephenson (2012) for example, give a good overview of some important models of CM, such as Applied Behavior Analysis, Decisive Discipline, Positive Behavior Intervention and Support. All these models set different foci on CM. Our following considerations concerning CMC however, are less based on models of CM but focus more on the main tasks of CM embracing individual support and group leadership. The objective of this section, therefore, is to explain some basic pillars that are essential for CMC according to the analysis of Dollase (2012).

There is already evidence that teacher students’ pedagogical content knowledge causally influences their later beliefs (Blömeke, Buchholtz, Suhl, \& Kaiser, 2014). Thus, the question of which CMC are relevant is not trivial and we will discuss the question of which CMK may be relevant to the tension of individual support and leading a group with respect to establishing and maintaining an optimal learning environment for all students.

A fundamentally important issue is the knowledge of designing the interaction because the way an optimal learning environment is maintained, is as important as being achieved and maintained (Weinstein \& Evertson, 2006). A combination of warm support and high expectations has a demonstrable positive effect on the development of students (Hattie 2009). The optimal interaction style can be described as follows: Consistent (clear, transparent, and predictable) and caring (facing, looking after and involving) behavior creates an optimal basis for the learning of cognitive and social-emotional skills (Haep et al., 2014). Students with emotional and social difficulties, in particular, benefit from this method of interacting (Den Brok \& Levy, 2005; Hamre \& Pianta, 2001, 2005; Liew, Chen, \& Hughes, 2010; Reyes, Elias, Parker, \& Rosenblatt, 2013; Shechtman \& Leichtentritt, 2004; Sleeter, 2008; Weinstein et al., 2004). Moreover the quality of interaction correlates with teachers' perception of stress. As Friedman (1995, p. 937) notes: “There is consensus among researchers that the most common sources of teacher work stress stem from individual relationships with students.” Students' perception of the teacher through the teachers' eyes is highly correlated with burnout (Friedman, 1995).

How to interact also entails knowledge about prejudices. As Bowers and Flinders note, conventional CM is presented as if it were culturally neutral, rather than a white, middle-class construction (Bowers \& Flinders, 1991). Cultural responsiveness should be a competence of CM that is necessary to create supportive interactions with all students (Powell, McLaughlin, Savage, \& Zehm, 2001). However, Powell et al. note “... a kind of 
management that could be described as culturally responsive. What the shape of this management might be, however, is illusive and clearly difficult to define.” (Powell et al., 2001: p. 254). Weinstein, Tomlinson-Clarke and Curran (2004) propose five components relevant to Culturally Responsive Classroom Management (CCRCM): recognition of one's own ethnocentrism and biases, knowledge of students' cultural backgrounds, understanding of the broader social, economic, and political context of our educational system, ability and willingness to use culturally appropriate classroom management strategies and, finally, commitment to establish caring classroom communities. These steps of dealing with knowledge about individuals are relevant in social perception research.

An important dimension of interaction style in teaching profession is caring. Caring is important in CCRCM (Lo \& Howard, 2009) and also for individual support which is specifically addressed in Evertson and Weinstein's (2006) definition with respect to the cognitive, emotional, and moral development of adolescents.

On the other hand, CM also includes other skills for dealing with a large study group and the potential problems related to such a situation (Dollase, 2012; Kounin, 1970). Knowledge about groups is essential for CMC. The key components of the teaching profession are the capacity to manage complexity of the public and sociometric structures (Dollase, 2012; Loewenberg Ball \& Forzani, 2009).

In addition, in CM research, the importance of Technologies of the Self is clearly seen as a prerequisite for development-promoting and health-preserving behavior and for addressing the many skills required for dealing with a larger group of young people in a school context. The ability of teacher students to reflect on themselves and to develop appropriate ideas about the reality of school and their required behavior is very important as well as to regulate their own aggressive feelings and impulsive behavior (Steins, Haep, \& Wittrock, 2015).

In summary, it can be concluded that a binding and consistent canon of CMC certainly does not literally exist worldwide. But there are some major topics such as a supportive interaction style both on the individual and group level, reflection competence and knowledge of systematic Technologies of the Self. Table 4, that is relevant to study 2, gives an overview of CMC that we have put together for our research.

\section{What Should Teacher Students Do with Respect to Learning CM?}

How can CMK be conveyed in such a way that it can also be applied in everyday working life? The answer to this question is important. Knowledge can be very volatile and sometimes it is not necessarily transferred to competencies. The short time available for the placement of CMC should be used as profitably as possible.

It is certain that teacher students appreciate CMC (Dicke et al., 2015; Stephenson \& O'Neill, 2012). O'Neill and Stephenson (2012) report that completion of CM courses leads to feeling better prepared. However, the whole sample was prepared to manage misbehavior to some extent only, and was confident in using only half of the strategies that they were familiar with. Therefore, it seems reasonable that the relevant education stages must be taken to practice CMK as an effective behavioral knowledge in universities. In order to adequately prepare teachers to deal with challenging situations, it might not be sufficient to only teach the knowledge (e.g., knowledge related to social psychology such as attribution, social comparison, reactance, emotion psychology, and social perception). In addition, a special training of appropriate behavior might be necessary (Forzani, 2014; Loewenberg Ball \& Forzani, 2009, 2010; Trent, 2013; van Tartwijk, den Brok, Veldman, \& Wubbels, 2009; Winitzky \& Kauschak, 1995).

To put it together, the best way to teach CMC to future teachers is still not clear. Jones (1996) pointed out that "little work has been done to determine the most effective methods of educating teachers."(p. 515).

\section{Effects of Classroom Management Contents}

One important finding of the effects of CMC on teacher students is that they feel to be more effective and confident. Cooper and Yan (2015) reported an increase in teachers' confidence and competence: A positive correlation was found between teachers' level of satisfaction in relation to their training experiences and their confidence in their own competence to deal with students' problematic behaviors. Likewise, O'Neill et al. (2012) reported that teacher students felt better prepared after the completion of CM.

Dicke et al. (2015) investigated the effects of classroom management training on novice teachers' perceived $\mathrm{CM}$ skills and well-being, by comparing it to the effects of stress management training or no training. Results of the effects on CM variables provide evidence that participating in CM training leads to higher perceived CM skills for all participants. 
However, Rushton (2000) notes that efficacy will be felt probably after a certain time of experience, "as the interns began to state feelings about willingness to take risks and as they increased in confidence... shifted from just wanting to be popular with their students to being able to maintain strict and consistent discipline.” (p. 375).

\section{Our Research}

The thoughts on the issues outlined above which CMC are necessary and how the knowledge can be implemented in teacher education are central guidelines of our research. Our research questions are:

1) What is the current status of the action knowledge of teacher students? Based on the research outlined above it is known that teacher students think they can behave as their teachers who were observed as successful. But what does this mean in terms of concrete actions in concrete school situations? Study 1 explores this question: What kind of practical knowledge do teacher students bring to the first CM seminar?

2) What are the necessary CMC based on the findings of study 1 ? Are all these contents ever being placed in a seminar? This question is important because CM remains mostly confined to a single-standing seminar. Study 2 explores these questions: Which necessary knowledge contents can be derived from study 1 ? Can it be placed in one single seminar?

3) What does CMK create with teacher students or what do teacher students make with CMK? Here, we examine the impact of CMK on imagined action ideas of teacher students (Study 3) and on real actions in school (Study 4). Table 1 gives an overview of the studies. All studies were conducted by three teacher educators. The investigations were approved by the University. The data had been collected during the past four years.

\section{Study 1}

The leading question is: What kind of action knowledge teacher students bring to the first CM seminar?

\subsection{Method}

\subsubsection{Sample and Setting}

158 teacher students, 31 male students (19.62\%) and 127 female students (80.38\%), with an average age of $M=$

Table 1. Overview about the present research.

\begin{tabular}{|c|c|c|c|c|}
\hline & Study 1 & Study 2 & Study 3 & Study 4 \\
\hline Research questions & $\begin{array}{c}\text { What practical } \\
\text { knowledge do teacher } \\
\text { students have? }\end{array}$ & $\begin{array}{l}\text { What is the general level of } \\
\text { knowledge? Should all the } \\
\text { knowledge ever be placed } \\
\text { in a seminar? }\end{array}$ & $\begin{array}{c}\text { Does scientific } \\
\text { knowledge improve } \\
\text { practical } \\
\text { knowledge? }\end{array}$ & $\begin{array}{c}\text { How do teacher } \\
\text { students deal with } \\
\text { scientific knowledge } \\
\text { in practice? }\end{array}$ \\
\hline Sample & 158 teacher students. & 17 teacher students. & 58 teacher students. & 13 teacher students. \\
\hline Method & $\begin{array}{l}\text { Cross-section. } \\
\text { Imaginations of one's } \\
\text { own behavior as } \\
\text { teachers in about } 5 \\
\text { challenging situations } \\
\text { in the classroom at the } \\
\text { beginning of } \\
\text { a seminar. }\end{array}$ & $\begin{array}{l}\text { Longitudinal section } \\
\text { (T1 at the beginning of } \\
\text { seminar, T2 after } 5 \text { months). } \\
\text { CMK test of } 7 \text { topics in CM } \\
\text { at the beginning and end of } \\
\text { the seminar. Knowledge } \\
\text { acquisition: } \\
\text { correctness of } \\
\text { answers/self-estimation. }\end{array}$ & $\begin{array}{l}\text { Longitudinal section (T1, } \\
\text { T2 after } 5 \text { months). } \\
\text { Practical knowledge to } 5 \\
\text { specific imagined } \\
\text { problematic situations at } \\
\text { the beginning of the } \\
\text { seminar, and } 5 \text { specific } \\
\text { imagined problematic } \\
\text { situations at the end of } \\
\text { the seminar } \\
\text { Open-constructed } \\
\text { response. }\end{array}$ & $\begin{array}{l}\text { Longitudinal section } \\
\text { (4 - } 5 \text { observations } \\
\text { and feedbacks } \\
\text { during } 6 \text { months). } \\
\text { Observations of } \\
\text { teacher students in the } \\
\text { classroom by their } \\
\text { teacher educators. } \\
\text { Information on } \\
\text { subjective issues } \\
\text { through feedback } \\
\text { sessions. }\end{array}$ \\
\hline Results & $\begin{array}{c}\text { Uncertain practical } \\
\text { knowledge. }\end{array}$ & $\begin{array}{l}\text { Low level of knowledge (T1). } \\
\text { Knowledge can be improved } \\
\text { both in an objective } \\
\text { manner as well as in } \\
\text { self-estimation (T2). }\end{array}$ & $\begin{array}{l}\text { Theoretical knowledge } \\
\text { results in the } \\
\text { improvement of } \\
\text { practical knowledge } \\
\text { from T1 to T2. }\end{array}$ & $\begin{array}{l}\text { Practical knowledge } \\
\text { can be transferred only } \\
\text { imperfectly in } \\
\text { competencies within a } \\
\text { school semester. }\end{array}$ \\
\hline
\end{tabular}


24.87 years $(S D=3.95)$ participated in this study. These students are already in the final stage of their first training (university). For many of them, the seminars in which these data had been collected were already the last seminars in their education. The questionnaires were distributed and collected by three teacher educators in three seminars. Teacher students worked on the questionnaire only in the first session of each seminar.

\subsubsection{The Questionnaire}

The teacher students worked on the questionnaire voluntarily, in which five school situations were described (see the five situations above). In previous seminars we repeatedly asked teacher students to describe challenging situations that they had experienced or had observed. The situations were selected and compiled according to the number of times they were mentioned. We limited this study to 5 situations. The teacher students were instructed to describe how they would react in the situations as a teacher. The response format was open.

The situations were as follows: 1) A student always runs in the class during lesson. What do you do? 2) Although you have often talked to student $\mathrm{x}$ about $\mathrm{x}$ 's aggressive behavior towards the classmates (verbally, sometimes physically), nothing has changed. What do you do? 3) A student always comes late for class. How do you react? 4) A student constantly beats his/her next seat classmate with his/her fist. The neighbor does not fight back. What do you do? 5) One of your students has a speech impediment (e.g. stuttering) and, when he/she participates in class, is laughed at by classmates. How do you react? Teacher students worked on the questionnaire for at least 30 minutes.

\subsubsection{Data Analysis}

Altogether, the teacher students wrote 626 statements. The items were analyzed using content analysis (MAXQDA). The analysis is based on the statements of the students. An exploratory approach was preferred over a hypothesis-based approach. This means that the present study used an exploratory approach in order to obtain and aggregate further knowledge in the domains that are investigated through our research question (Patton, 2002).

\subsection{Results}

Table 2 shows the results of the content analysis. A very slight extent of double assignments is due to the category of "Linguistic Generalization". In the fourth column we give an example to illustrate what content is behind each category name. We have selected the fourth situation as an example because here all categories occurred. At first glance it is apparent that a high percentage of statements involve the possibility of a conversation with the students.

The contents (for a quick overview see Table 3) continue to be structured in positive reactions (praise), direct negative reactions in the situational context (penalties, admonishments, sanctions, exclusion, threats), the prospect of external support (talking with parents, talking with other professionals), the conversation with the student (student-call), and a neutral approach (ignoring). Since linguistic generalizations are not directly associated with teacher students actions, this category is omitted in the data reduction (Table 3). It is clear that in addition to negative behavioral patterns a tendency can be seen to seek external assistance.

\subsection{Discussion of Study 1}

Through study 1 we wanted to explore the state of the action knowledge of teacher students for challenging situations. Our approach has some methodological limitations. First, the choice of situations is limited; the results would probably be different if different situations were presented. Second, all teacher students had to work on the same questions, thus, it is not certain whether some of them have influenced each other while working on the questionnaires. Third, the answers of the teacher students only addressed their imaginations therefore, no statements about the actual actions of teacher students can be made, hence, the study only gives a first impression of teacher students' CMK level about coping with these specific situations.

The results show that punishment, admonishment, exclusion and threatening are parts of the behavioral repertoire in teacher students' imaginations. This response pattern clearly shows that the teacher students have not intensively dealt with the influence and importance of the public and social structure yet as noted by Dollase (2012). Many seem not to know that inducing shame for example, can work but it is not a constructive interaction style. These teacher students would likely keep to punishing styles without further knowledge. Loewenberg 
Table 2. Practical knowledge of teacher students in about five challenging situations. As an example, row 4 shows teacher students answers to situation $4^{1}$.

\begin{tabular}{|c|c|c|c|}
\hline Category & $\%(f)$ & Actions & Example of statement \\
\hline Praise & $0.48(3)$ & Verbal praise. & $\begin{array}{l}\text { Praising the student who } \\
\text { does not fight back. }\end{array}$ \\
\hline Punishment & $12.30(77)$ & $\begin{array}{l}\text { Class council, class entry, locking the } \\
\text { door, putting down, limited detentions, } \\
\text { detentions, consequences, privileges, } \\
\text { punishment. }\end{array}$ & Punishing the student severely. \\
\hline Admonishment & $14.06(72)$ & $\begin{array}{l}\text { Directly addressing the } \\
\text { student in the class. }\end{array}$ & $\begin{array}{l}\text { Admonishing the student } \\
\text { and asking about the reason. }\end{array}$ \\
\hline Ignoring & $4.15(26)$ & Not paying attention. & $\begin{array}{l}\text { I consider myself out of the class; } \\
\text { students should handle } \\
\text { this by themselves. }\end{array}$ \\
\hline $\begin{array}{l}\text { Teacher-parents } \\
\text { meetings }\end{array}$ & $14.70(92)$ & Involving parents. & Searching parent-teacher meeting. \\
\hline $\begin{array}{l}\text { Teacher-student } \\
\text { meetings }\end{array}$ & $37.06(232)$ & Talking with students. & $\begin{array}{l}\text { I lead a discussion with the } \\
\text { student who strikes. }\end{array}$ \\
\hline $\begin{array}{l}\text { Teacher-teacher } \\
\text { meetings }\end{array}$ & $13.58(85)$ & $\begin{array}{l}\text { Meetings with the principal, } \\
\text { a social worker }\end{array}$ & $\begin{array}{l}\text { If necessary, measures should be } \\
\text { considered (school } \\
\text { psychologist, social worker). }\end{array}$ \\
\hline Exclusion & $0.80(5)$ & $\begin{array}{l}\text { Student out of class, } \\
\text { suspending from school }\end{array}$ & $\begin{array}{l}\text { The student who has bullied should be } \\
\text { thrown out of the classroom. }\end{array}$ \\
\hline Threat & $0.80(5)$ & Threatening with exclusion (e.g.) & $\begin{array}{l}\text { I put the bat on a single table right close } \\
\text { to me (after I threatened him that I would } \\
\text { do so if he should continue to beat). }\end{array}$ \\
\hline Generalizing language $^{2}$ & $2.07(13)$ & z.B. bully, victim. & $\begin{array}{l}\text { Bring bullies and victims face } \\
\text { to face and discuss. }\end{array}$ \\
\hline
\end{tabular}

${ }^{1}$ A student constantly beats the next seat classmate with his/her fist. The neighbor does not fight back. What do you do? ${ }^{2}$ In few cases this category leads to a double categorization.

Table 3. Five different actions in challenging situations.

\begin{tabular}{cc}
\hline Action theme & Proportion \% \\
\hline Talking with students & 37.06 \\
External assistance & 28.28 \\
Negative reactions & 27.96 \\
Ignoring & 4.15 \\
Positive reactions & 0.48 \\
\hline
\end{tabular}

Ball and Forzani (2010) described it as a danger, when a scientific oriented behavior is not trained: "Some teachers left to learn through experience to manage their classrooms using harshly punitive methods..." (p. 42).

Teacher students chose to talk to the students quite often as a reaction when facing a critical situation. This response pattern however, does not reveal how they would create the conversation. Do they use the conversation to punish the students individually or to understand the behavior of the student? Do they use it to find a good solution or a constructive agreement? We also did not include the combination of different solutions in this analysis.

In order to respond adequately to the situations in Study 1, teacher students must have a set of CMK. It would be helpful to be familiar with sanctions at school, with the difficulties of penalties and the public; basics for supportive interaction design and the method of talking to students are relevant.

\section{Study 2}

Analogous to the tension of CM, individual support and leading a group, we have designed a seminar that provides the scientific basis to understand how the challenges of teaching to a large group can be mastered (master- 
ing of public, complexity and social structures of students). The focus of knowledge is therefore clearly on the interaction design in relation to a wide range of school situations. The questions that will be examined here are: Is all the knowledge placed in a seminar? How is the initial level of the teacher students CMK? Is real knowledge related to perceived knowledge?

\subsection{Methods}

\subsubsection{Sample and Setting}

17 teacher students, who were preparing for different types of schools, participated in this study. The sample is composed of 3 men and 14 women. The age varies from 19 to 27 years old $(M=22.92 ; S D=2.69)$. Teacher students took part in a theory-practice seminar. They learned the theory about CM for one semester and then they taught a double lesson weekly "Social Learning" for 5 months either in a comprehensive school or an elementary school. The data reported here refers to the semester before teaching.

\subsubsection{Data Collection}

All students worked on a knowledge test in the first session (T1) and final session (T2) of the seminar. Each student had a personal code, which allowed an allocation of data. Since the test to T2 teacher students had insight to their test of T1: They could decide on the basis of responses to T1, whether they had been improved and could optionally give another proof of their knowledge.

Description of the CMK Test. The same test was therefore presented to T1 and T2. Each test consists of 37 questions on CMC. Each question can be worked on by two details. First, a scale from 0 (I do not know) to 5 (I know a lot) is available, which depicts a self-estimation of the knowledge. Second, each teacher student when having given a self-estimation of 3 or higher on this scale has to give a proof of knowledge by a keyword.

The test includes seven subject areas, each of which plays a major role in the seminar. Table 4 gives an overview of these areas and also illustrates the keywords through which one's knowledge can be demonstrated by way of example.

\section{Table 4. CMC for a CMK test.}

\begin{tabular}{|c|c|c|c|c|}
\hline Topic & N/Items & Item/Example & Keyword/Example & Competence $^{1}$ \\
\hline $\begin{array}{l}\text { Classroom } \\
\text { management }\end{array}$ & 9 & $\begin{array}{l}\text { What makes the difference } \\
\text { between a } 1: 1 \text { lesson and a } \\
28: 1 \text { lesson? }\end{array}$ & Public. & $\begin{array}{l}\text { Encouraging students to } \\
\text { learn by appropriate } \\
\text { challenges and friendly and } \\
\text { promoting interaction style. }\end{array}$ \\
\hline $\begin{array}{l}\text { Technology of the } \\
\text { self }\end{array}$ & 8 & $\begin{array}{c}\text { What is the Technology } \\
\text { of the Self? }\end{array}$ & $\begin{array}{l}\text { Rational emotive } \\
\text { behavior therapy (REBT). }\end{array}$ & $\begin{array}{c}\text { Recognize and regulate one's } \\
\text { own irrational problems } \\
\text { quickly; support students } \\
\text { with emotional regulation. }\end{array}$ \\
\hline $\begin{array}{l}\text { Ecological } \\
\text { psychology }\end{array}$ & 6 & What is the third educator? & Environment. & $\begin{array}{l}\text { Establish and maintain the } \\
\text { environment physically } \\
\text { adequate; physically } \\
\text { adequate interaction design. }\end{array}$ \\
\hline Group dynamics & 4 & $\begin{array}{l}\text { How can class cohesion } \\
\text { be determined? }\end{array}$ & Sociometry. & $\begin{array}{c}\text { Recognize disintegration and } \\
\text { integrate outsiders; detect } \\
\text { and counteract the large } \\
\text { differences in } \\
\text { performance and values. }\end{array}$ \\
\hline $\begin{array}{l}\text { Positive behavior } \\
\text { support systems }\end{array}$ & 4 & $\begin{array}{l}\text { What is the system of } \\
\text { sanctions? }\end{array}$ & $\begin{array}{c}\text { Transparent } \\
\text { behavior-consequences-systematics. }\end{array}$ & Make appropriate sanctions. \\
\hline Social perception & 3 & $\begin{array}{l}\text { What are key features in } \\
\text { person perception? }\end{array}$ & Sex. & $\begin{array}{l}\text { Identify and revising } \\
\text { prejudices; friendly behavior. }\end{array}$ \\
\hline $\begin{array}{l}\text { Development and } \\
\text { education }\end{array}$ & 3 & $\begin{array}{l}\text { Which dimensions of } \\
\text { education are } \\
\text { known to you? }\end{array}$ & Freedom within limits. & $\begin{array}{l}\text { Formulate a reasonable } \\
\text { formula for expectations; } \\
\text { caring and friendly } \\
\text { interaction style. }\end{array}$ \\
\hline
\end{tabular}

\footnotetext{
${ }^{1}$ These competencies might be associated with the knowledge.
} 
General Questions. At T1, the students were asked how well they felt prepared by their previous seminars to the teaching practice. At this point, they could assign a grade from 1 (very good) to 6 (unsatisfactory). For the second assessment, students could mark how helpful the concrete seminar was to prepare for the future work life.

\subsubsection{Data Analysis}

The data were calculated with the aid of a statistics program (SPSS version 21). Two experts coded the keywords in conclusive or inconclusive. A correct keyword was rated with one point. If doubts about the quality of the keyword existed but it was pointed in the right direction, a half point was awarded. Was the keyword wrong or was given none, 0 points were awarded. So the total score could be determined with a minimum of 0 points and a maximum of 37 points. A repeated measure analysis for the change in self-estimation and CMK from T1 to T2 was conducted. The results of previous seminars to T1 compared with the usefulness of the seminar to T2 were evaluated

\subsection{Results}

\subsubsection{Description of the Data}

At T1 we determined between .5 and 13 points of 37 points; at T2 between 6 and 22 points of 37 points. Concerning self-estimation the range shifts from .50 to 2.73 (T1; 5 is maximum) to 2.38 to 5 points (T2; 5 is maximum).

The evaluation for the training received ( 1 to 6 , with 6 being the worst score) is for T1 from 2 to 6 , for T2 from 1 to 3 .

\subsubsection{Inferential Testing of Change}

Table 5 provides an overview of the statistical parameters. Generally, a significant change is detected $(F(3,12)=$ 121. 97, $p<.001, \eta^{2}=.97$ ): All values rise in the desired direction. Tests of within-subjects contrasts show that this is true for any field of CMK. Teacher students consider themselves not only better in all fields of knowledge $\left(M T 1=1.70 ; M T 2=3.28 ; F(1,18.89)=169.98, p<.001, \eta^{2}=.92\right)$, but also they know actually more $(M T 1=$ 5.73; $\left.M T 2=13.73 ; F(1,480)=72.06, p<.001, \eta^{2}=.84\right)$. The seminar compared with the previous education is rated as important and useful $\left(M T 1=3.97 ; M T 2=2.10 ; F(1,26.13)=51.41, p<.001, \eta^{2}=.79\right)$.

With regard to the achievable maximum, the results show that the teacher students' self-estimation in terms of CMK increased by $100 \%$; CMK increased by $174.68 \%$. However, since teacher students can only reach $37.11 \%$ of the maximum score, the basis level comes to $13.51 \%$.

\subsection{Discussion of Study 2}

Study 2 explored the issues whether essential CMC based on the findings of Study 1 are ever to be placed in one single seminar. This question is important because CM remains mostly confined to a single-standing seminar.

The study has some methodological limitations. First, the teacher students had to provide only minimal evidence of their knowledge; so we cannot formulate a statement about the real extent of their knowledge. In addition, the teacher students all took the same test, so we cannot claim whether there was any interference, although this has not been observed. We have only a preliminary overview of progress in CMK acquisition.

Table 5. Statistical characteristics of self-estimation of CMK, actual knowledge and evaluation of CMC, usefulness to T1 (at the beginning of a seminar) and T2 (the end of the seminar).

\begin{tabular}{|c|c|c|c|c|c|}
\hline \multirow[t]{2}{*}{ Variable } & \multicolumn{2}{|c|}{$\mathrm{T} 1$} & \multicolumn{2}{|c|}{$\mathrm{T} 2$} & \multirow[t]{2}{*}{$\eta 2$} \\
\hline & M & SD & M & SD & \\
\hline Self-estimation & 1.70 & .50 & 3.28 & .50 & .92 \\
\hline Knowledge & 5.73 & 3.18 & 13.73 & 5.16 & .84 \\
\hline Usefulness of Study/Seminar & 3.97 & 1.12 & 2.10 & .63 & .79 \\
\hline
\end{tabular}

T1: Usefulness of the previous studies for the professional context. T2: Usefulness of the seminar for the professional context. The higher was the value of usefulness, the worse the rating got. 
In summary, one can say that the teacher students acquire knowledge on CM in the seminar and this acquisition is estimated also realistically insofar as they correctly perceive this increase. A key finding is, however, that the knowledge increase occurs, but this remains relatively low relative to the possible level of knowledge. This may be due to the breadth of knowledge content. When addressing CMC, Jones (2006) noted that it is still an unsolved problem whether CMC should address the breath or depth of knowledge. A qualitative study that explicitly dealt with a similar concept involving the review of the CMC, showed that the teacher students especially appreciated the knowledge of Technologies of the Self (Steins, Haep, \& Wittrock, 2015). However, it would be a serious difficulty when other contents would have to be excluded in favor of Technologies of the Self.

\section{Study 3}

Knowledge is not necessarily correlated with actions. Study 1 shows that the teacher students rarely had systematic ideas for reaction in various challenging situations. This study is now investigating how CMK, as described in Study 2 affects practical knowledge for challenging situations. Again, we dealt with teacher students' imaginations in this study. The research question is: Does CMK improve imaginations of the action requirements?

\subsection{Methods}

\subsubsection{Sample and Setting}

58 teacher students (16 male and 42 female students with an average age of $M=24.14$ years; $S D=3.29$ ) worked on a questionnaire with 5 situations at the beginning of a CM seminar (T1) and after the CM seminar (T2). Here, just as Study 1 the answer format was open. The teacher students worked individually and needed 30 minutes in average to complete the questionnaire.

\subsubsection{The Questionnaire}

We created a set of 10 different situations. Some of them were also included in Study 1. Teacher students were instructed to imagine how they would feel in such situations and describe what they would do as a teacher. Table 6 gives an overview about the situations. We worked with two versions. Version A is included in situations 1 5 and given at T1, version B entails situations 6 - 10 and is worked on at T2.

\subsection{Data Analysis}

Unlike Study 1 we did not analyze the contents, but we had set standards in advance, based on CM research in order to evaluate the answers. Thus, we created a normative template. Table 6 shows the ideal answers. Each situation was weighed equally with 0.20 points. Generally, there is a minimum of 0 points and a maximum of 1 point. A repeated measure analysis for the change of students' imaginary reactions from T1 to T2 was conducted.

\subsection{Results}

At T1 teacher students answers are evaluated with $M=0.29$ points $(S D=.19)$, at T2 the value increases to $M=.42$ $(S D=.15)$. This difference is significant, $F(1,57)=25.78, p<.001, \eta 2=.31$. At T1 the teacher students could solve one situation out of five in average; at T2 they could solve 2 situations out of five in average.

\subsection{Discussion of Study 3}

Study 3 was conducted with regard to the effectiveness of CMK and dealt specifically with the effects of CMK described in Study 2 on the imaginary action performances of students when facing challenging situations. Our template to evaluate the answers is certainly not without attack points (see Table 6). The fact that some behaviors of the students would be possibly handled by other researchers differently shows us a problem of CM research for teacher students: Research does not always come to concrete conclusions about the appropriateness of behavior and the question is that whether $\mathrm{CM}$ research might be more concrete in the application. This question would have to be urgently discussed. Study 3 comes to results that can be seen here as a first attempt in identifying changes of action ideas. 
Table 6. Challenging situations in the classroom-Examples of responses from teacher students and ideal actions.

\begin{tabular}{cc}
\hline Situation/Sample response & Ideal response and evaluation \\
\hline
\end{tabular}

1. A student always runs in class. What will you do?

Only wait and see if it repeated more often.

I remind the student to follow the rules and remember the consequences, which we If problems are so massive that they endanger the lesson, I have to intervene.

This can be done through extra-curricular

arrangements, but the student can also be sanctioned by exclusion (0 P). have previously placed in the class. [Remembering rules and consequences; RRC] If the student does not keep this in mind, the student gets a consequence.

[Result/Sanctions; C]

If the student still does not keep this in mind, I talk to him/her face to face and try to understand his/her motives. We determine what he/she can do in order to comply with the rules. [Conversation, empathy, assistance/Agreement for rule compliance; Con]

2. Although you have often talked to students about their aggressive behavior towards classmates (verbal and sometimes physical), nothing changes. What will you do?

Treat bullying as a topic-show a video. (0)

Since the behavior despite frequent warnings (reference to rules and consequences) cannot be changed, I make it possible for the student to participate in a training course. [Intervention Training/Assistance/Alternatives to act]

Before that I make sure that the student exhibits the behavior not only in my classes but also in other classes by factual discussions with my colleagues. [Talk with colleagues/parents/discussion with school psychologists/Exclude: behavior only during one's own teaching]

3. Students come late for class. How do you react?
Classroom door will be locked at an agreed time (about 7 mins.). Students will have to study that lesson at home. (0 P).
RRC
Con

4. A student constantly beats his classmate next to him on the arm with his fist. The neighbor does not fight back. What will you do?

$\begin{gathered}\text { I continue to observe the situation and ask the } \\ \text { bully to answer challenging questions about the } \\ \text { lesson. }(0 \mathrm{P}) .\end{gathered}$
$\begin{gathered}\text { Toward the student who does not fight back: I reinforce him/her for his/her social } \\ \text { behavior. [Conversation with the affected students/reinforce affected student]. I ask } \\ \text { him/her to get help in a more clear way. I take occasion and talk with the class about } \\ \text { the difference between tattling and getting help. Talking with the two students. }\end{gathered}$

5. One of your students has a speech impediment (e.g. stuttering) and, when he participates in class, he/she is laughed at by classmates. How do you react?

Speak to the class, introduce the students to the class and tell the students that this student has a problem, that happens in our society and I urge all students to be respectful and patient. $(0 \mathrm{P})$.

Intervention measure on „being respectful to each other. “If this does not work:

Conversations in small groups [measure Respectfully working together, talking to small groups, reminding them of rules] Respectively (Once an affected pupil/student concerned comes into focus: 0 P.)

Face to face Conversation with the affected student: affirm that there will be a solution. [Responding to affected students, assistance]

6. A student frequently puts his/her hand up, but is rarely paid attention to, complaining loudly (during your lesson). How do you behave?

I apologize to the student for my behavior, and

I promise him that I will pay more attention to him/her next time. (0 P).

Signal perception, friendly smile [Perception, memory of rules] Talk about it face to face [Personal interview, outside the class context].More options [one's own critical reflection]

7. A student is constantly running around the classroom. On your demand he/she always has a reason. There is paper, which he/she wants to throw, she/he wants to open the window, she/he wants to wash his/her hands, etc. How do you react?

I make it clear that nobody can get up anytime
he/she wants and he/she has the personal

RRC

responsibility to organize him/her self better

$\mathrm{C}$

Con

8. A student throws paper beads in the classroom. How do you react?

I exhort the student, but firstly do not threaten

RRC with consequences. (0 P).

$\mathrm{C}$

Con

9. You get to know that a few students want to beat a classmate after school. How do you react? 


\section{Continued}

I indirectly talk in class about the question whether there were problems.

If this does not work, I would explain that it's come to my attention (without naming their names) and would discuss the issue. (0 P).
Direct call (Clarity and borders, clarify expectations, I write down expectations; students have to sign it.) [Talking to the students and written agreement]

Next day: Talking to the students concerned

[Talking to the affected students]

10. A student is consistently excluded by classmates. How do you react?

I behave passively and try to observe why the classmate is excluded and if the classmate is affected by this.

If the fellow is unhappy with it, I would try to indirectly convey. I would not directly convey because students have to try establish friendships themselves and cope independently with problems. Should I be asked for help, I can provide assistance. (0 P)
Conversation with the affected student and integration of the affected student in extracurricular activities [Conversation with student affected, extracurricular involvement, assistance, support] Intervention for the affected students [Intervention within the class context]

In summary it can be said that the assumed reactions of students significantly improve after the transfer of CMK as a scientifically validated way for dealing with challenging situations. After a CM seminar teacher students probably know that rules and consequences should be transparent and that they should behave according to them. They also probably know that a supportive individual conversation helps to understand students' motive and to find agreements that can help to deal with problems. However, just as noted in study 2, the level does not increase impressive.

\section{Study 4}

Until now, we have only presented results that took place in a classic setting of academic knowledge. Thus, we can gain knowledge of what teacher students know and whether CMK increases through its mediation. However, the results do not reveal if and how the knowledge is implemented in the real classroom context. So there are no statements possible about competences (Matt, Rauch, \& Dallasega, 2014). With this fourth and final study, we want to approach the question of what teacher students might do with CMK when they start teaching or vice versa: Does the acquisition of CMK lead to competencies that are observable in the instructional setting? Table 4 shows cautious statements about a relationship between knowledge and competencies (row 5). We explored this question in a seminar, in which we were able to observe students while teaching after they completed a CM seminar. The study is an observational study in which situations are first documented and are then classified and analyzed in the second step.

At this point, teacher students have acquired the CMK already. The research questions are: Can CMK be transferred to competence? What processes and problems can be observed in the process of implementation?

\subsection{Sample, Setting, Procedure}

The sample consists of 10 female (A, B, C, D, E, F, G, H, I, J) and 3 male teacher students (K, L, M). These teacher students taught in small teams (Team 1: A, B; Team 2: C, K; Team 3: D, E, L; Team 4: F, G; Team 5: H, I and Team 6: J, M) to $7^{\text {th }}$ graders in Social Learning (90 min per week about 5 months; for more detail about the program see Steins \& Haep, 2015).

Regularly, the teacher students were observed by their teacher educators and received feedback (in average 1 4 observations with feedback). Along with lessons and feedbacks the teacher educators made protocols of their observations. In addition, each week the teacher students attended a seminar to prepare lessons and discuss about problems and solutions in the group. The combination of observation in the field and conversation with feedback had the advantage that not only behavior but also inner processes were available.

\subsection{Results}

Table 7 provides an overview of the problems of the teacher students at school. These problems are as complete as possible and compiled based on the protocols of observations and feedback sessions made by the teacher 
Table 7. Problems and strengths of teacher students in practice.

\begin{tabular}{|c|c|c|}
\hline $\begin{array}{l}\text { Teacher } \\
\text { students }\end{array}$ & Problems and strengths observed & Quotes from feedback setting \\
\hline A & Gets annoyed quickly by disorders. & $\begin{array}{l}\text { Has the feeling that she is too impatient; reacts too fast and too strict; lack of } \\
\text { alternative behavior. }\end{array}$ \\
\hline B & $\begin{array}{l}\text { Gets annoyed quickly and is often } \\
\text { involved in students' misconduct. }\end{array}$ & $\begin{array}{l}\text { Finds it difficult to be consistent and not to engage in discussions; "I know, that's } \\
\text { not right, but sometimes I have noticed that I've been looking forward, or am re- } \\
\text { lieved that E. (a special student) is not present in the class and I actually like it." }\end{array}$ \\
\hline $\mathrm{C}$ & $\begin{array}{l}\text { To be consistent is difficult. C } \\
\text { provides students a platform for } \\
\text { misconduct. }\end{array}$ & $\begin{array}{l}\text { When she talks determinedly, she may still feel that she would no longer be } \\
\text { friendly. }\end{array}$ \\
\hline $\mathrm{D}$ & $\begin{array}{l}\text { Gets easily distracted by students' } \\
\text { comments; too soft in dealing with } \\
\text { the students. }\end{array}$ & $\begin{array}{l}\text { Although she may be able to deal with annoyance, she notices that she gets really } \\
\text { angry in front of a particular student (M). She gets upset about his behavior. }\end{array}$ \\
\hline $\mathrm{E}$ & $\begin{array}{l}\text { Is friendly with students but } \\
\text { quickly irritated by students' } \\
\text { comments. }\end{array}$ & $\begin{array}{l}\text { Wants to learn to respond more professionally to personal comments of students } \\
\text { which hurts her ("You are very small, Ms X"). }\end{array}$ \\
\hline $\mathrm{F}$ & $\begin{array}{l}\text { Uncertain in teaching the subject; } \\
\text { friendly with the students; laughs } \\
\text { at students' inappropriate behavior. }\end{array}$ & $\begin{array}{l}\text { Wants to prepare the lesson better to teach better and be less of a comrade in the } \\
\text { students' eyes. }\end{array}$ \\
\hline G & $\begin{array}{l}\text { Shows good structure in teaching } \\
\text { and friendly interactions style. }\end{array}$ & $\begin{array}{l}\text { A particular student is a huge disappointment to her. Thinks that she might be } \\
\text { disappointed because she knows that this particular student can do better. She } \\
\text { perhaps has the idea of "the hardworking dear girl" and now reacts stronger and } \\
\text { more irritated at disorders, even though they may not be so bad. }\end{array}$ \\
\hline $\mathrm{H}$ & Friendly, but annoyed. & $\begin{array}{l}\text { Wants to be more consistent in dealing with disturbances and personal } \\
\text { conversations; wants to give more concrete instructions; wants to give less } \\
\text { attention to disorders. }\end{array}$ \\
\hline I & Friendly, but annoyed. & $\begin{array}{l}\text { She wants to be liked; she is upset because she knows that a particular class could } \\
\text { do better. Wants to learn to be more consistent in responding to disturbances and } \\
\text { give them less attention; wants to draw a stronger boundary between her and } \\
\text { students. }\end{array}$ \\
\hline $\mathrm{J}$ & $\begin{array}{l}\text { Friendly handling, } \\
\text { smooth teaching. }\end{array}$ & $\begin{array}{l}\text { Wants to be better with time management in complex situations; wants to handle } \\
\text { the negative behavior among students in a better way. }\end{array}$ \\
\hline $\mathrm{K}$ & Friendly handling and motivating. & $\begin{array}{l}\text { Sometimes feels overwhelmed in unstructured phases and do not always know } \\
\text { how to respond; will try not to put himself under pressure and try to teach in a less } \\
\text { tense way(in improvised unstructured phases). }\end{array}$ \\
\hline $\mathrm{L}$ & $\begin{array}{l}\text { Friendly and able to } \\
\text { handle the structure }\end{array}$ & Wants to be more consistent. \\
\hline $\mathrm{M}$ & $\begin{array}{l}\text { Friendly handling, } \\
\text { smooth teaching. }\end{array}$ & $\begin{array}{l}\text { Recognized the importance of working on relationships and wants to maintain this } \\
\text { for the future. }\end{array}$ \\
\hline
\end{tabular}

educators. The data provide a concrete description of problems and strengths and give some key insights to answer the research questions.

\subsubsection{Main Categories of Problems}

The problems of teacher students are divided in two main categories: 1) emotional problems and 2) practical problems. A key theme of emotional problems concerns the interaction with certain students. Practical problems such as instructing clearly, giving a good structure about lessons, improving time management, were rare. Only two of 13 students had no problems with interaction (J, M); one of them (M) had no problems at all, neither with practical issues, nor with emotional issues. We now describe the problems in more detail.

\subsubsection{Emotional Problems}

Annoyance at Students as Individuals. Six students were annoyed by one or more students, a recurring theme (A, B, D, G, H, and I). A had the feeling that she was too impatient, B was quickly annoyed and D was working 
hard to better deal with situations in which she was annoyed. She was internally often really upset when a special student showed certain behaviors. E was irritated greatly by comments of individual students ("You are very small, Ms E”). These comments annoyed her and made her puzzled. G was particularly irritated by a certain student, $\mathrm{H}$ and I were visibly annoyed by the behavior of certain students.

Undesired Actions toward Students' Misbehaviour. These six students worked hard to learn not to draw too much attention to the misbehavior of individual students. A, reflected self-critically that she exhorted too fast and too severe and she would often miss behavior alternatives. B can often be watched responding to a perceived wrong deed. C provides students with a great stage for their misconduct. D can be distracted very fast by comments from students. $\mathrm{H}$ and I want to explicitly give less attention to disorders. Four of the students (B, C, H and I) and an additional student, L, have the impression that they are inconsistent when it comes to students and work consistently during these months to point the rules and consequences to students. All these students define the goal of wanting to be consistent. B stresses in particular that it was very difficult for her to be consistent and "not to engage in discussions".

Evaluation of Own Emotional Reactions. Eight students (A, B, C, D, E, G, I, and K) report internal problems that would have not necessarily been seen only by observing. B reflected on the question, why it is so difficult for her to be consistent with students' misbehavior: "I know that's not right, but sometimes I have noticed that I've been looking forward to not having $\mathrm{E}$ in my class, or felt relieved that $\mathrm{E}$ (a special student) is not in the classroom.” A judges it as bad, that she feels very impatient when in her eyes something does not work out as planned. In our observations these processes are not noticed, but the teacher students have really strong emotions because of these self-reflections. Also C's difficulty to respond consistently to students is understandable in a deeper feedback session: If she talks more decisive she has the feeling that she would no longer be friendly. $\mathrm{F}$ has the tendency to be friends with students and evaluates it as dysfunctional that she always laughs along when students show misconduct. G, whom is a very good teacher and has a friendly behavior with the students at the observation level, reported in a feedback interview that she is extremely disappointed especially with one special student. She says that in the beginning of teaching, she established a good rapport with this student. The student was very attentive. But now she is often distracted. $G$ is extremely disappointed, because she actually knows that the student could do better. But she evaluates herself: "You have perhaps the idea of 'the dear hardworking girl' and now react stronger and more irritated at disorders, even though they may not be so bad. I am so often annoyed, because I had built up a relationship with the student and want to be liked.” K, a good teacher, showing a friendly and motivating interaction style with the students, sometimes feels overwhelmed and do not always know how to react (especially in improvised unstructured phases).

\subsection{Practical Problems}

Three students, F, H and J wanted to structure better certain topics of teaching. Only three students demonstrated observable structural issues: F, J and H. F's observable inadequate teaching structure is due to her lack of preparation. $\mathrm{H}$ must learn to formulate more specific instructions. $\mathrm{J}$ has time management problems in complex situations.

\subsection{Discussion of Study 4}

Study 4 explored the question of the transfer of CMK to teaching in the classroom. The data were obtained by field observations and feedback sessions and then categorized according to emerging themes. The aim of the study is, however, not an exhaustive categorization of emerging problems in the field of action, but to explore how the students use their knowledge of CM. Methodically our approach is certainly influenced by subjective distortions, in so far as a field observation cannot be completely objective and also subsequently made protocols may be distorted. The data are therefore to be understood as an initial and exploratory approach.

The results of this study point to several aspects. On one hand, they show that practical problems like clarifying instructions, structuring lessons, improving time management, relatively rarely occurred compared to emotional problems, whose main share was based on interaction problems with certain students. With interaction problems some negative emotions are associated, such as being annoyed and irritated. These emotions are related to different processes that are part of the diverse personalities of the teacher students. In the feedback sessions it very quickly became clear that the teacher students have taken a lot of knowledge from the theoretical part and also can use it. However, it is mostly not yet possible, to implement the knowledge in the real situations 
so that they quickly can regulate their strong negative emotions. CMK helped teacher students to become aware of the discrepancy between actual thinking, feeling and acting and the known standard of thinking and acting. The bridging of this distance needs to be trained laboriously.

In our opinion this is the most important finding of this study: The students recognize their problems. They can recognize them because they were previously familiar with CMC. They often failed to achieve these standards. Particularly illustrative is the insight of G, that it is her personal expectation associated with a particular gender related stereotype, triggering an extremely strong disappointment about the student. Although she understands her personal contribution, her insight may still not conform to the reality of her perception. However, the design of the study does not assure, whether the teacher students talked about the discrepancy between actual and desired thinking and also feeling and behaving because they are being watched by the teacher educators. We had no comparison group to make sure that teacher students would experience this discrepancy in an unobserved setting.

\subsection{General Discussion}

To summarize, we can answer our research questions as follows: During their training to become teachers, teacher students have little opportunity to adapt their action imaginations from their apprenticeship of observation to scientific evidence, so that they frequently choose the average acceptable approach when dealing with problems (Study 1). The mediation of CMC leads to an increase in CMK (Study 2), and subjective action ideas became more compatible with scientific evidence (Study 3). The increase in knowledge does not mean that CMK can be implemented by all teacher students in appropriate actions in the classroom itself. However, because of their knowledge teacher students experience a discrepancy between their real actions in real contexts and standards set by CMC, demonstrating that CMK may set standards of behavior and give an orientation after all (at least in the presence of teacher educators; Study 4).

Much of the research here can be criticized. In our arrangement of CMC we accentuated social-psychological research and included Technologies of the Self as a method of knowledge implementation and behavior verification. The focus of knowledge transfer is particularly on the interaction models and reasons for a constructive interaction style, what allows teacher students to understand other people better and to improve their perspective taking capability. Very different modules can be set in a CM seminar. In our opinion interaction skills are the red line of all CMC. Furthermore, the limitation of action ideas on challenging situations is certainly one-sided. Analogous to our focus on interaction design and the previous experience of the teacher students we have dealt with situations where there are instructional interruptions and adverse interaction loops and a negative class climate may rise if situations were not handled with care. Overall, in some of the studies reported we cannot exclude effects of social desirability (for example, Study 3 and 4). We have already addressed other methodological limitations in the specific discussions of our studies.

Despite many methodological and content restrictions, however, we think we can come to the overall conclusion that it is necessary for teacher students to come to study CMC. Much more time would be necessary to acquire CM skills. Time left for CM must be used to mediate knowledge and also create the possibility of a constructive framework where individual feedback and discussions (within a scientifically-based framework) with reference to realistic teaching is possible. In so far we have come to conclusions Hattie (2009) had already summarized which note that the combination of knowledge, reflection, experience and if needed, training, is a necessary step in teacher education.

\section{Conclusion}

Our general questions "What is needed, what is possible, how is it done at school?" we want to answer to these questions based on our empirical studies: It is essential for future teachers to have a broad knowledge of interaction design in the school context. This knowledge includes knowledge about individual caring and knowledge about group management. Thus, it includes of course all facets of heterogeneity. Technologies of the Self are necessary to be included to give teacher student the possibility of reflecting and adjusting their own knowledge and own behavior. However, it will hardly be possible to secure all this knowledge in addition to other knowledge assets that are declared by other researchers as necessary. That's why it would be important that CM research put together a minimum canon of CMC. Our observations in the field show that it is necessary for teacher students to be also accompanied over a long period, as long as they can transfer their knowledge in actions relia- 
bly. It would be desirable if future teacher training would pay more attention on interaction design and CMC to ensure the quality of this basic competency.

In spite of numerous valuable insights of CM research, teacher education does not guarantee this. Numerous publications have addressed this problem. Zeichner (2005) criticizes clearly the lack of professional education of teachers; in Germany the Referendariat was cut down from 24 months to 18 months. Until now CMK is not implemented as a fixed syllabus in teacher education.

Finally, our results suggest that CMK is an important resource for teacher students and heightens their selfefficacy. We recommend including more substantial CMK in teacher education. Teacher students need considerable time to act on an empirically driven basis. Thus, it is important to combine CMK with actions and to have feedbacks on these actions as well. Our recommendations for Teacher Education can be summarized as follows: Aspiring teachers not only need more time to acquire CMK but also need more time to integrate CMK in their behavior repertoire within a protected framework. There is an urgent need for convincing research to investigate which CMK is most effective for better future schooling, both for the teachers and the students.

\section{Acknowledgements}

This research is part of the Identity/Role-Orientation project in the "Bund-Länder-Program" and is supported by the German Bundesministery of Education and Research. We are most grateful to Andrea Schlicker who assisted us in collecting the data and coordinating the project.

\section{Compliance with Ethical Standards}

The authors confirmed that they complied with ethical guidelines.

\section{Conflict of Interest}

The authors have no conflict of interest.

\section{References}

Balli, S. J. (2011). Pre-Service Teachers’ Episodic Memories of Classroom Management. Teaching and Teacher Education, 27, 245-251. http://dx.doi.org/10.1016/j.tate.2010.08.004

Blömeke, S., Buchholtz, N., Suhl, U., \& Kaiser, G. (2014). Resolving the Chicken-or-Egg Causality Dilemma: The Longitudinal Interplay of Teacher Knowledge and Teacher Beliefs. Teaching and Teacher Education, 37, 130-139.

http://dx.doi.org/10.1016/j.tate.2013.10.007

Bowers, C. A., \& Flinders, D. J. (1991). Culturally Responsive Teaching and Supervision: A Handbook of Staff Development. New York, NY: Teachers College Press.

Brouwer, N., \& Korthagen, F. (2005). Can Teacher Education Make a Difference? American Educational Research Journal, 42, 153-223. http://dx.doi.org/10.3102/00028312042001153

Cooper, P., \& Yan, Z. (2015). Some Possible Effects of Behaviour Management Training on Teacher Confidence and Competence: Evidence from a Study of Primary School Teachers in Hong Kong. Educational Studies, 41, 156-170. http://dx.doi.org/10.1080/03055698.2014.955739

Den Brok, P., \& Levy, J. (2005). Teacher-Student Relationships in Multicultural Classes: Reviewing the Past, Preparing the Future. International Journal of Educational Research, 43, 72-88. http://dx.doi.org/10.1016/j.ijer.2006.03.007

Dicke, T., Elling, J., Schmeck, A., \& Leutner, D. (2015). Reducing Reality Shock: The Effects of Classroom Management Skills Training on Beginning Teachers. Teaching and Teacher Education, 48, 1-12.

http://dx.doi.org/10.1016/j.tate.2015.01.013

Dollase, R. (2012). Classroom Management. Theorie und Praxis des Umgangs mit Heterogenität. (Classroom Management. Theory and Practice of Heterogenity). Schulmanagement Handbuch, 142. München: Oldenbourg.

Evertson, C. M., \& Weinstein, C. S. (2006). Classroom Management as a Field of Inquiry. In C. M. Evertson, \& C. S. Weinstein (Eds.), Handbook of Classroom Management. Research, Practice, and Contemporary Issues (pp. 3-16). Mahwah, NJ: Lawrence Erlbaum Associates.

Forzani, F. M. (2014). Understanding “Core Practices” and "Practice-Based” Teacher Education: Learning from the Past. Journal of Teacher Education, 65, 357-368. http://dx.doi.org/10.1177/0022487114533800

Friedman, I. A. (1995). Student Behavior Patterns Contributing to Teacher Burnout. Journal of Educational Research, 88, 281-289. http://dx.doi.org/10.1080/00220671.1995.9941312 
Haep, A., Steins, G., Wilde, J., Haep, A., Steins, G., \& Wilde, J. (2014). Soziales Lernen Sekundarstufe I (Social Learning Secondary School I). Donauwörth: Auer.

Hamre, B. K., \& Pianta, R. C. (2001). Early Teacher-Child Relationships and the Trajectory of Children's School Outcomes through Eighth Grade. Child Development, 72, 625-638. http://dx.doi.org/10.1111/1467-8624.00301

Hamre, B. K., \& Pianta, R. C. (2005). Can Instructional and Emotional Support in the First-Grade Classroom Make a Difference for Children at Risk of School Failure? Child Development, 76, 949-967.

http://dx.doi.org/10.1111/j.1467-8624.2005.00889.x

Hattie, J. (2009). Visible Learning. London: Routledge.

Howe, E. R. (2006). Exemplary Teacher Education: An International Review. Educational Philosophy and Theory, 38, 287297. http://dx.doi.org/10.1111/j.1469-5812.2006.00195.x

Jones, V. (2006). How Do Teachers Learn to Be Effective Classroom Managers? In C. M. Evertson, \& C. S. Weinstein (Eds.), Handbook of Classroom Management. Research, Practice, and Contemporary Issues (pp. 887-908). Mahwah, NJ: Lawrence Erlbaum Associates.

Kounin, J. S. (1970). Discipline and Group Management in Classrooms. New York: Holt, Rinehart and Winston.

Liew, J., Chen, Q., \& Hughes, J. N. (2010). Child Effortful Control, Teacher-Student-Relationships, and Achievement in Academically At-Risk Children: Additive and Interactive Effects. Early Childhood Research Quarterly, 25, 51-64. http://dx.doi.org/10.1016/j.ecresq.2009.07.005

Lo, A., \& Howard, K. M. (2009). Mobilizing Respect and Politeness in Classrooms. Linguistics and Education, $20,211-216$. http://dx.doi.org/10.1016/j.linged.2009.07.001

Loewenberg Ball, D., \& Forzani, F. M. (2009). The Work of Teaching and the Challenge for Teacher Education. Journal of Teacher Education, 60, 497-511. http://dx.doi.org/10.1177/0022487109348479

Loewenberg Ball, D., \& Forzani, F. M. (2010). Teaching Skillful Teaching. Educational Leadership, 68, 40-45.

Löfström, E., \& Poom-Valickis, K. (2013). Beliefs about Teaching: Persistent or Malleable? A Longitudinal Study of Prospective Student Teachers’ Beliefs. Teaching and Teacher Education, 35, 104-113.

http://dx.doi.org/10.1016/j.tate.2013.06.004

Lortie, D. (1975). Schoolteacher: A Sociological Study. London: University of Chicago Press.

Matt, D. T., Rauch, E., \& Dallasega, P. (2014). Mini-Factory-A Learning Factory Concept for Students and Small and Medium Sized Enterprises. Science Direct, 17, 178-183. http://dx.doi.org/10.1016/j.procir.2014.01.057

O’Neill, S., \& Stephenson, J. (2012). Does Classroom Management Coursework Influence Pre-Service Teachers’ Perceived Preparedness or Confidence? Teaching and Teacher Education, 28, 1131-1143.

http://dx.doi.org/10.1016/j.tate.2012.06.008

Patton, M. Q. (2002). Qualitative Research and Evaluation Methods (3rd ed.). Thousand Oaks, CA: SAGE.

Piwowar, V., Thiel, F., \& Ophardt, D. (2013). Training in Service Teachers' Competencies in Classroom Management. A Quasi-Experimental Study with Teachers of Secondary Schools. Teaching and Teacher Education, 30, 1-12. http://dx.doi.org/10.1016/j.tate.2012.09.007

Powell, P. R., McLaughlin, H. J., Savage, T. V., \& Zehm, S. (2001). Classroom Management: Perspectives on the Social Curriculum. Upper Saddle River, NJ: Merril/Prentice-Hall.

Reupert, A., \& Woodcock, S. (2010). Success and Near Misses: Pre-Service Teachers’ Use, Confidence and Success in Various Classroom Management Strategies. Teaching and Teacher Education, 26, 1261-1268. http://dx.doi.org/10.1016/j.tate.2010.03.003

Reyes, J. A., Elias, M. J., Parker, S. I., \& Rosenblatt, J. L. (2013). Promoting Educational Equity in Disadvantaged Youth: The Role of Resilience and Social-Emotional Learning. In S. Goldstein, \& R. B. Brooks (Eds.), Handbook of Resilience in Children (2nd ed., pp. 349-370). New York: Springer. http://dx.doi.org/10.1007/978-1-4614-3661-4_20

Rushton, S. P. (2000). Student Teacher Efficacy in Inner-City Schools. The Urban Review, 32, 365-383. http://dx.doi.org/10.1023/A:1026459809392

Shechtman, Z., \& Leichtentritt, J. (2004). Affective Teaching: A Method to Enhance Classroom Management. European Journal of Teacher Education, 27, 323-333. http://dx.doi.org/10.1080/0261976042000290822

Sleeter, C. (2008). Equity, Democracy, and Neoliberal Assaults on Teacher Education. Teaching and Teacher Education, 24, 1947-1957. http://dx.doi.org/10.1016/j.tate.2008.04.003

Steins, G., \& Haep, A. (2015). Social Learning and Rational-Emotive Education: An Exploratory Investigation of Students' Perceptions. Psychology, 6, 1096-1107. http://dx.doi.org/10.4236/psych.2015.69107

Steins, G., Haep, A., \& Wittrock, K. (2015). Rational-Emotive and Cognitive-Behavior Therapy in Teacher Education: A Systematic Technology of the Self for Classroom Management. Creative Education, In Press. 
Stough, L. M. (2006). The Place of Classroom Management and Standards in Teacher Education. In C. M. Evertson, \& C. S. Weinstein (Eds.), Handbook of Classroom Management. Research, Practice, and Contemporary Issues (pp. 909-924). Mahwah, NJ: Lawrence Erlbaum Associates.

Stoughton, E. H. (2007). “How Will I Get Them to Behave?”: Pre-Service Teachers Reflect on Classroom Management. Teaching and Teacher Education, 23, 1024-1037. http://dx.doi.org/10.1016/j.tate.2006.05.001

Trent, J. (2013). From Campus to Classroom: A Critical Perspective on Approximations of Practice in Teacher Education. Research Papers in Education, 28, 571-594. http://dx.doi.org/10.1080/02671522.2012.710246

van Tartwijk, J., den Brok, P., Veldman, I., \& Wubbels, T. (2009). Teacher’s Practical Knowledge about Classroom Management in Multicultural Classrooms. Teaching and Teacher Education, 25, 453-460. http://dx.doi.org/10.1016/j.tate.2008.09.005

Voss, T., Kunter, M., \& Baumert, J. (2011). Assessing Teacher Candidates’ General Pedagocical/Psychological Knowledge: Test Construction and Validation. Journal of Educational Psychology, 103, 952-969. http://dx.doi.org/10.1037/a0025125

Weiner, F. E., \& Lingelbach, H. (1995). Teaching Expertise: Theoretical Conceptualizations, Empirical Findings, and Some Consequences for Teacher Training. In R. Hoz, \& M. Silberstein (Eds.), Partnerships of Schools and Institutions of Higher Education in Teacher Development (pp. 293-302). Beer-Sheva: Ben Gurion University of the Negev Press.

Weinstein, C. S., Tomlinson-Clarke, S., \& Curran, M. (2004). Toward a Conception of Culturally Responsive Classroom Management. Journal of Teacher Education, 55, 25-38. http://dx.doi.org/10.1177/0022487103259812

Winitzky, N., \& Kauchak, D. (1995). Learning to Teach: Knowledge Development in Classroom Management. Teaching \& Teacher Education, 11, 215-227. http://dx.doi.org/10.1016/0742-051X(94)00029-6

Wolff, C. E., van den Bogert, N., Jarodzka, H., \& Boshuizen, H. P. A. (2015). Keeping an Eye on Learning: Differences between Expert and Novice Teachers' Representations of Classroom Management Events. Journal of Teacher Education, 66, 68-85. http://dx.doi.org/10.1177/0022487114549810

Zeichner, K. (2005). Becoming a Teacher Educator: A Personal Perspective. Teaching and Teacher Education, 21, 117-124. http://dx.doi.org/10.1016/j.tate.2004.12.001 